\title{
Effect of foliar application with some treatments on summer squash (Cucurbita pepo, $L$.) tolerance to high temperature stress
}

\author{
El-Shoura A.M.
}

Vegetable Research Department, Horticulture Research Institute, A.R.C., Giza Egypt Received: 20 April 2020/Accepted 15 June 2020/Publication date: 30 June 2020

Two field experiments were carried out in a private farm at Boqtares Village, Dakahlia Governorate, Egypt during the seasons of 2017 and 2018 on summer squash under open field conditions. The main objective was to study the effect of foliar application with some treatments i.e., vitamin $\mathrm{C}$, vitamin $\mathrm{E}$, potassium silicate, salicylic acid, glycine betaine, urea, calcium nitrate, boric acid, zn chelate and control (water spray) on summer squash (Cucurbita pepo, L. cv. Eskandarani) tolerance to high temperature stress. Generally, the foliar application of glycine betaine at $75 \mathrm{ppm}$ resulted in vigor squash plant as expressed by vegetative growth parameters i.e., plant height, number of leaves per plant, leaf area, plant fresh weight and plant dry weight compared with other foliar treatments. Moreover, the highest values of fruit yield and quality components, i.e., fruit length, fruit diameter, average fruit weight, number of fruits per plant and fruit yield per plant and per feddan were recorded with potassium silicate application at $100 \mathrm{ppm}$ followed by vitamin $\mathrm{C}$ at $100 \mathrm{ppm}$ and vitamin $\mathrm{E}$ at $100 \mathrm{ppm}$ treatments. Also, potassium silicate recorded the highest values of TSS \% in squash fruits and total chlorophyll in leaves compared with other treatments. The highest percentage of $\mathrm{N}, \mathrm{P}$ and $\mathrm{K}$ were recorded with glycine betaine and potassium silicate $\left(\mathrm{K}_{2} \mathrm{SiO}_{3}\right)$. The obtained results indicated, generally, that foliar applications of glycine betaine at $75 \mathrm{ppm}$ and potassium silicate at $100 \mathrm{ppm}$ to squash plants might be considered as an optimal treatment for the production of high vegetative growth, yield and fruit quality of squash under the environmental conditions of Dakahlia Governorate and other similar regions.
\end{abstract}

Keywords: summer squash, Cucurbita pepo, vitamins, antioxidants, high temperatures, yield.

\section{Introduction}

Summer squash (Cucurbita pepo, L.) is one of the most popular vegetable crops for human nutrition and is a highly polymorphic vegetable grown during summer in Egypt and all over the world. Also, squash is one of the most important cash crops, especially, in newly reclaimed areas of Egypt. Summer squash fruits are very low in calories (19 Kcal/100 g), moisture (94.8 g), edible portion $(94 \%)$ and have large amounts of fiber $(0.8 \mathrm{~g})$ (Tamer et al., 2010). Heat stress is defined as the rise in temperature beyond a threshold level for a period sufficient to cause permanent damage to plant growth and development. It is a complex function of intensity, duration, and the rate of the increase in temperature. The frequently exposed to heat stresses resulted in adverse effect on the growth of plants which affect the metabolism and yield (Dreesen et al., 2012; Rollins et al., 2013). The soil temperature increase resulting from the increase in air temperature maybe even stronger when accompanied by a drought-induced decline in soil water content (Sekhon et al., 2010). Hence, this study suppose that some treatments could be playing a major role in mitigation the advance effect of heat stress on squash growth and yield.

Vitamin $\mathrm{C}$ is a vitamin known as growth regulating factor which influences many biological processes. It is currently considered as a plant growth regulator due to its effect on cell division, differentiation and various growth factors (Amin et al., 2007). It increases nucleic acid content, especially RNA and acts as co-enzyme in the enzymatic reactions and involved in photosynthesis and respiration (Mazher et al., 2011 and Salama et al., 2014). Vitamin E is a necessary ingredient for biosynthesis of the coenzyme thiamine pyrophosphate, which plays an important role in carbohydrate metabolism (Hendawy and Ezz El-Din, 2010) and helps to provide an optimal environment for photosynthetic machinery (Jaleel et al., 2006).

Corresponding Author: Alaa M. El-Shoura, Cross Pollinated vegetables Research Department, Horticulture Research Institute, ARC, Giza, Egypt.

E-mail: dalaaagri@yahoo.com 
Salicylic acid (SA) is a phenolic compound and natural constituent of plant, it involves in plant resistance to different pathogen attacks. It plays physiological roles in plant growth, nutrients uptake, flower induction, stomata movement and activity of photosynthesis and enzymes (Iqbal et al., 2014). Also, (Abd El-Mageed et al., 2016 and Abd - Elaziz et al., 2019) showed that, the vegetative growth, yield and its components were maximized due to salicylic acid foliar application. Silicon ( $\mathrm{Si}$ ) is deposited as silica in the plant cell walls, improving cell wall structural rigidity and strength, plant architecture and leaf erectness. It has been reported that $\mathrm{Si}$ applied by external foliar treatments has beneficial effects on plant growth and plays an important role in tolerance of plants to environmental stresses (Liang et al., 2015 and Rizwan et al., 2015). Omar (2017) reported that, foliar application with silicon caused an increase in vegetative growth and yield and its components of cucumber and Abd - Elaziz et al. (2019) reported the same results on summer squash.

Zinc is one of the important elements necessary for the plant, it is includes in the composition of the essential amino acids and affects many vital operations of the plant. In addition, it plays a role in the formation of some important enzymes, stimulating the metabolism of proteins and carbohydrates and integrity of nucleic acids and cell membranes (Lalelou and Fateh, 2014). Moreover, calcium $(\mathrm{Ca})$, one of the essential nutrients for plants, plays a major role in the initiation of many signal transduction processes in higher plant cells, polar growth, cell division and helps to maintain the chromosome structure and hormone regulated growth and development (Ashraf, 2004). It activates phospholipase, arginine kinase and adenosine tri phosphatase (ATPase) enzymes (Mumivand et al., 2010).

Boron (B) has physiological important roles in the strength of cell wall which is a part of the cell membranes in addition to its vital role in respiration, cell wall structure, carbohydrate metabolism, cell division, hormonal regulation and fertilization thus boron supply is necessary for improving fruits yield and quality of vegetable crops (Esringü et al., 2011). Likewise, several investigations showed that the vegetative growth, yield and quality of vegetable crops positively responded to boron foliar supplies (Abd El-Gawad and Osman 2014; Buczkowska et al., 2016)...

Furthermore, the major source of protein in plant tissues is urea such source of nitrogen and amino acids. The requirement of nitrogen of amino acids in essential quantities is well known as a instrument to increase the vegetative growth, yield and its components. Amino acids are the fundamental ingredients for the process of protein synthesis. Studies have proved that amino acids can directly or indirectly influences the physiological activities in plant growth and development. The foliar application of urea caused an enhancement in plant growth, fruits yield and its components of cucumber (Xu et al., 2004) and squash (Abd El-Aal et al., 2010). Glycine betaine is amino acid which is considered as a vital activator that is rapidly absorbed and transported within the plant part, very common to be accumulated during salt stress and plays a fundamental role in osmotic adjustment in plants (Szabados and Savoure, 2010).

Therefore, this investigation aimed to improve plant growth and fruits yield and its components of squash grown under high temperature stress conditions by using different foliar applications.

\section{Materials and Methods}

Two field experiments were conducted in a private farm at Boqtares Village, Dakahlia Governorate, Egypt under open field conditions during the growing of seasons 2017 and 2018 to study the effect of foliar application with ten treatments i.e. vitamin $\mathrm{C}$ at $100 \mathrm{ppm}$, vitamin $\mathrm{E}$ at 100 $\mathrm{pm}$, potassium silicate at $100 \mathrm{ppm}$, salicylic acid at $50 \mathrm{ppm}$, glycine betaine at $75 \mathrm{ppm}$, urea at $1 \%$, calcium nitrate at $0.5 \%$, boric acid at $60 \mathrm{ppm}$, zinc chelate at $50 \mathrm{ppm}$ and control (water spray) on summer squash (Cucurbita pepo, L. cv. Eskandarani) tolerance to high temperature stress. Before sowing, random soil samples $(0-30 \mathrm{~cm}$ depth) from different places of the planting field were collected and some important chemical and physical properties were analyzed according to A. O. A. C. (1990) is given in Table 1.

The prevailing climatic conditions of the meteorological station during the two growing seasons of squash at Dakahlia Governorate are listed in Table 2. 
Table 1: Physical and chemical proprieties of the experimental soil during 2017 and 2018 seasons.

\begin{tabular}{|c|c|c|}
\hline Soil proprieties & 2017 & 2018 \\
\hline & 1- Physical analysis & \\
\hline Course sand (\%) & 1.49 & 1.51 \\
\hline Fine sand (\%) & 22.69 & 23.04 \\
\hline Silt & 17.77 & 17.65 \\
\hline Clay (\%) & 58.05 & 57.80 \\
\hline $\mathrm{Ca} \mathrm{Coz} \mathrm{( \% )}$ & 1.71 & 1.75 \\
\hline Soil texture & Clay loam & Clay loam \\
\hline & 2- Chemical analysis & \\
\hline pH & 8.05 & 7.95 \\
\hline $\mathrm{Ec}\left(\mathrm{dsm}^{-1}\right.$ at $\left.25^{\circ} \mathrm{C}\right)$ & 1.38 & 1.40 \\
\hline Organic matter & 1.44 & 1.67 \\
\hline Available N (ppm) & 70.33 & 73.04 \\
\hline Available P (ppm) & 14.5 & 15.08 \\
\hline Available K(ppm) & 67.11 & 71.93 \\
\hline Available Fe (ppm) & 3.05 & 3.22 \\
\hline Available Mn (ppm) & 1.44 & 1.61 \\
\hline Available Zn (ppm) & 1.50 & 1.60 \\
\hline $\mathrm{Ca}^{2+}$ & 1.13 & 1.14 \\
\hline $\mathbf{M g}^{2+}$ & 0.87 & 0.84 \\
\hline $\mathrm{Na}^{2+}$ & 1.08 & 1.10 \\
\hline $\mathrm{So}_{4}^{2+}$ & 1.33 & 1.43 \\
\hline
\end{tabular}

Table 2: Meteorological recorded of Dakahlia Governorate ${ }^{*}$ during the seasons 2017 and 2018.

\begin{tabular}{lcccccc}
\hline \multirow{2}{*}{ Month } & \multicolumn{3}{c}{$\mathbf{2 0 1 7}$} & \multicolumn{3}{c}{$\mathbf{2 0 1 8}$} \\
\cline { 2 - 7 } & Max. Temp. & Min. Temp. & Avg. Temp. & Max. Temp. & Min. Temp. & Avg. Temp. \\
\hline June & 32.1 & 20.1 & 26.1 & 33.7 & 22.5 & 28.1 \\
July & 38.5 & 25.0 & 31.7 & 41.0 & 25.3 & 33.1 \\
August & 35.3 & 23.8 & 29.5 & 38.7 & 22.6 & 30.6 \\
September & 32.1 & 20.9 & 26.5 & 34.3 & 21.0 & 27.6 \\
October & 26.7 & 17.6 & 22.2 & 29.8 & 21.2 & 25.5 \\
November & 22.6 & 13.3 & 18.0 & 30.0 & 17.1 & 20.1 \\
December & 20.2 & 11.9 & 17.0 & 22.0 & 14.8 & 18.4 \\
\hline
\end{tabular}

* Source: Meteorology data from Central Lab. for Agricultural Climate, Agricultural Research Center, Egypt.

Squash seeds (Cucurbita pepo, L. cv. Eskandarani) were sown directly in the field on $1^{\text {th }}$ week of July during both seasons of 2017 and 2018. The treatments were arranged in a randomized complete blocks design (RCBD) with three replicates. The plot area was $\left(15 \mathrm{~m}^{2}\right)$ comprised of three ridges $(5 \mathrm{~m}$ length and $1 \mathrm{~m}$ width) with $0.5 \mathrm{~m}$ spacing between plants in row. After germination, plants were thinned to one plant per hill. Squash plants were sprayed by the allocated treatments twice during the growing seasons, at 25 days after sowing (at the fourth true leaf stage) and one week later. The NPK fertilizers were added at a rate of $200 \mathrm{~kg} /$ fed. as ammonium sulphate $(20.5 \% \mathrm{~N}), 100 \mathrm{~kg}$ / fed. as super phosphate $\left(15.5 \% \mathrm{P}_{2} \mathrm{O}_{5}\right)$ and $100 \mathrm{~kg} /$ fed. as potassium sulphate $\left(48 \% \mathrm{~K}_{2} \mathrm{O}\right)$, nitrogen and potassium were added in three portions; first portion after one month, the second portion after two months from sowing and the third portion during the flowering stage. While, phosphorus fertilizer was added during soil preparation before sowing. The recommended cultural practices i.e., irrigation, pest and diseases control, etc. of summer squash plant for commercial squash production in the area were applied as recommended by the Ministry of Agriculture.

\section{The recorded data:}

\section{Vegetative growth parameters:}

A random sample of 5 plants from each plot was taken at 75 days after sowing to determine plant height $(\mathrm{cm})$, number of leaves per plant, leaf area $\left(\mathrm{cm}^{2}\right)$, plant fresh weight $(\mathrm{g})$ and plant dry weight $(\mathrm{g})$. 


\section{Yield and its components:}

At harvest stage the mature fruits of squash were harvested twice every week along the harvesting season. At the harvesting time, fruit length $(\mathrm{cm})$, fruit diameter $(\mathrm{cm})$, average fruit weight (g), number of fruits per plant, fruit yield per plant $(\mathrm{kg}$ ) and fruit yield per feddan (ton) were calculated.

\section{Chemical constituents:}

$\mathrm{N}, \mathrm{P}, \mathrm{K}$ and $\mathrm{Si}$ contents of leaves were determined according to the methods described by Okalebo et al. (2002), Pregl (1945), Murphy and Riley (1962) and APHA (1992). Total chlorophyll was estimated in leaves accordance to Marquard and Tipton, (1987). Total soluble solids content (TSS $\%$ ) was estimated in the juice of the fresh fruits using a hand refractometer and Vitamin C content was estimated accordance to Mazumdar and Majumder, (2003).

\section{Statistical Analysis:}

All data were statistical analysis accordance to the procedure out lined by Snedecore and Cochran (1982) and the treatment means were compared using significant at 0.05 and 0.01 levels of probability (LSD). Data were statistically analyzed using Co- STAT computer software program

\section{Results and Discussion}

\section{Vegetative growth:}

The present data in Table 3 illustrated the effect of foliar treatments (vitamin $\mathrm{C}$ at $100 \mathrm{ppm}$, vitamin $\mathrm{E}$ at $100 \mathrm{ppm}$, potassium silicate at $100 \mathrm{ppm}$, salicylic acid at $50 \mathrm{ppm}$, glycine betaine at 75 $\mathrm{ppm}$, urea at $1 \%$, ca nitrate at $0.5 \%$, boric acid at $60 \mathrm{ppm}$, zn chelate at $50 \mathrm{ppm}$ and control (water spraying)) on vegetative growth of summer squash. The vegetative growth traits (plant height, number of leaves per plant, leaf area and fresh and dry weight of plant) were positively influenced by all foliar application treatments during the first and second seasons compared with control (untreated plants). Whereas, the best plant growth was obtained when glycine betaine sprayed at $75 \mathrm{ppm}$ followed by urea at $1 \%$ compared with other treatments and the lowest values were correlated with the control (untreated plants) during the first and second seasons under this study. Generally, glycine betaine at $75 \mathrm{ppm}$ gave the highest mean magnitudes during the both seasons as $(25.00$ and $25.33 ; 2452.61$ and $2476.14 ; 645.00$ and $645.00 ; 105.90$ and 106.38 ) for number of leaves per plant, leaf area, fresh and dry weight traits, respectively during the two seasons. The positive effect of glycine betaine on squash growth may be due to playing a major role in increase plant tolerance to some abiotic stress such as drought and high temperatures (Salem, 2018). The main cause for that vigour of squash in response to urea foliar application compared to the other treatments might be due to that the urea contains the most nutritional element such as nitrogen which is more needed if compared with the requirements of plant to amino acids, also, it is a source of nitrogen fertilizer had a major role in improvement the metabolism processing due to the importance of nitrogen in building carbohydrates, protein and fats in the plant tissues (Abd El- All et al., 2013). In addition, the favorable impact of Si application resulted in its ability to hamper both biotic pressures caused by pest attacks and plant diseases, as well as biotic pressures, including physical pressures such as water logging, drought, high temperature and chemical pressures as nutrient deficiencies and metal toxicity (Rizwan et al., 2015; Abd-Elaziz et al. 2019). Also, Elwan and El-Shatoury (2014) and Abd El-Mageed et al. (2016) illustrated that exogenous salicylic acid (SA) application, significantly, increased all squash growth parameters (plant length, number of leaves per plant, leaf area per plant and fresh and dry weights per plant). Furthermore, the increased vegetative growth parameters might be attributed to increased cell division and cell elongation induced by aforementioned treatments. The tabulated results indicated, clearly, their modes of action in regulating and modulating the physiological processes on growth and development of summer squash under the study via ion uptake and transport, photosynthetic rate, membrane permeability and transpiration. El-Tohamy et al. (2008) found that foliar application of vitamin $C$ increases plant fresh weight of eggplant. Vitamin E could be attributed to the influence of these components upon the endogenous phytohormones specially the growth promoters such as Auxins, cytokinins and gibberellins (Mady, 2009). The obtained results are in agreement with those reported by Majeed, (2010) on calcium; Noman (2011) on vitamin C in pumpkin; Jafari et al. (2015) 
on silicon; Nasrollahzadeh et al. (2015) on boric acid; Abd El-Mageed et al. (2016) on salicylic acid and Al-Rubaye and Atia, (2016) on zinc.

Table 3: Effect of foliar application with some treatments on the vegetative growth traits of summer squash plants during two seasons of 2017 and 2018.

\begin{tabular}{|c|c|c|c|c|c|c|}
\hline \multirow{2}{*}{ Treatments } & \multicolumn{2}{|c|}{ Plant height (cm) } & \multicolumn{2}{|c|}{$\begin{array}{c}\text { Number of leaves } \\
\text { / plant }\end{array}$} & \multicolumn{2}{|c|}{ Leaf area $\left(\mathrm{cm}^{2}\right)$} \\
\hline & 2017 & 2018 & 2017 & 2018 & 2017 & 2018 \\
\hline Control & 38.33 & 40.00 & 10.33 & 11.33 & 2060.39 & 2068.79 \\
\hline Vitamin $C$ at $100 \mathrm{ppm}$ & 50.33 & 52.00 & 19.00 & 21.67 & 2307.10 & 2311.62 \\
\hline Vitamin $E$ at 100 ppm & 48.33 & 49.00 & 16.67 & 19.00 & 2345.54 & 2349.89 \\
\hline Potassium silicate at $100 \mathrm{ppm}$ & 51.00 & 52.67 & 17.67 & 18.33 & 2336.82 & 2336.59 \\
\hline Salicylic acid at 50ppm & 47.33 & 46.00 & 20.33 & 20.33 & 2289.77 & 2294.61 \\
\hline Glycine betaine at $75 \mathrm{ppm}$ & 60.00 & 62.33 & 25.00 & 25.33 & 2452.61 & 2476.14 \\
\hline Urea at $1 \%$ & 55.67 & 57.33 & 22.00 & 24.67 & 2406.45 & 2421.47 \\
\hline Ca nitrate at $0.5 \%$ & 52.00 & 51.33 & 20.67 & 23.33 & 2336.78 & 2342.39 \\
\hline Boric acid at $60 \mathrm{ppm}$ & 49.67 & 52.33 & 19.67 & 21.33 & 2357.24 & 2355.62 \\
\hline Zn chelated at $50 \mathrm{ppm}$ & 53.00 & 54.67 & 20.67 & 20.33 & 2374.86 & 2384.06 \\
\hline LSD $1 \%$ & 3.483 & 3.990 & 2.077 & 3.820 & 46.594 & 47.490 \\
\hline LSD $5 \%$ & 2.542 & 2.910 & 1.516 & 2.793 & 34.008 & 34.660 \\
\hline
\end{tabular}

Table 3: Continued

\begin{tabular}{lcccc}
\hline & Traits & \multicolumn{2}{c}{ Plant fresh weight (g) } & \multicolumn{2}{c}{ Plant dry weight (g) } \\
\cline { 2 - 5 } Treatments & $\mathbf{2 0 1 7}$ & $\mathbf{2 0 1 8}$ & $\mathbf{2 0 1 7}$ & $\mathbf{2 0 1 8}$ \\
\hline Control & 345.00 & 344.67 & 49.18 & 50.82 \\
Vitamin C at 100 ppm & 591.67 & 593.33 & 86.20 & 87.67 \\
Vitamin E at 100 ppm & 508.33 & 511.67 & 72.23 & 72.93 \\
Potassium silicate at 100 ppm & 527.67 & 538.67 & 77.07 & 78.76 \\
Salicylic acid at 50 ppm & 581.00 & 589.67 & 81.92 & 84.66 \\
Glycine betaine at 75 ppm & 645.00 & 645.00 & 105.90 & 106.38 \\
Urea at 1 \% & 626.00 & 630.00 & 97.79 & 101.31 \\
Ca nitrate at 0.5 \% & 575.30 & 580.00 & 89.17 & 88.67 \\
Boric acid at 60 ppm & 580.67 & 585.00 & 78.84 & 79.70 \\
Zn chelated at 50 ppm & 594.33 & 611.67 & 79.38 & 82.93 \\
\hline LSD 1 \% & $\mathbf{1 0 . 6 3 5}$ & $\mathbf{2 1 . 9 4 0}$ & $\mathbf{4 . 0 2 0}$ & $\mathbf{6 . 3 9}$ \\
LSD 5 \% & $\mathbf{7 . 7 6 2}$ & $\mathbf{1 6 . 0 1 4}$ & $\mathbf{2 . 9 3 4}$ & $\mathbf{4 . 6 6}$ \\
\hline
\end{tabular}

\section{2- Yield and its components:}

The results in Table 4 showed that all treated plants exhibited the highest significant means of fruit length, average fruit weight, number of fruits per plant, total yield per plant and total yield per feddan, expect for fruit diameter compared to untreated plants (control) during the first and second seasons. Potassium silicate at $100 \mathrm{ppm}$ exhibited the highest means for all studied traits expect for fruit diameter traits followed by vitamin $\mathrm{C}$ at $100 \mathrm{pm}$ during the both seasons, respectively. Generally, summer squash plants treated with $100 \mathrm{ppm}$ potassium silicate recorded the highest mean of fruit length (14.94 and $15.86 \mathrm{~cm}$ ), average fruit weight (125.64 and $134.05 \mathrm{~g}$ ), number of fruits per plant (10.33 and 12.33), total yield per plant (1.30 and $1.65 \mathrm{~kg})$ and total yield per feddan (10.39 and 12.23 ton) followed by $100 \mathrm{ppm}$ vitamin $\mathrm{C}(13.98$ and $15.47 ; 121.88$ and $127.72 ; 9.67$ and $11.33 ; 1.18$ and $1.45 ; 9.42$ and 11.58) for aforementioned traits, respectively in both seasons. The obtained results showed that the increasing of fruit length, average fruit weight, number of fruits per plant, total yield per plant and per feddan (fruit yield) were obtained due to foliar application with potassium silicate at $100 \mathrm{ppm}$ followed by vitamin $\mathrm{C}$ at $100 \mathrm{ppm}$ and other treatments might be attributed to the increase of vegetative growth traits compared to untreated plants during the two seasons. These results are in agreement with those illustrated by Omar (2017) who illustrated that foliar application of potassium silicate at $100 \mathrm{ppm}$ caused; significant increase on cucumber fruit yield compared to control plants. With respect to total yield per plant and total yield per feddan, the lowest significant mean values for total yield per plant and total yield per feddan traits of squash fruits were derived from untreated plants compare to treated plants during the two seasons. Matichenkov and Bocharnikova (2008) found 
that cucumber yield was increased, significantly either by silicon application during the season or by soil Si applications. There are additional benefits for Si includes stimulation of fruit formation and accelerated fruit maturation. The positive effect of vitamin $C$ at $100 \mathrm{ppm}$ squash growth may be due to it is effect on cell division, differentiation and different growth parameters and increases nucleic acids content in the enzymatic reactions by which proteins, carbohydrates metabolized and interested in photosynthesis (Mazid et al., 2011). Youssef et al. (2017) showed that increasing vitamin C foliar application levels significantly increased fruit length, average fruit weight and total yield in both seasons as compared with untreated plants. (Abd El-Aal et al., 2010; Abd El- All et al., 2013) illustrated that increasing in total fruits as well as its physical properties might be attributed to that urea resulted a promotion effect on vegetative growth traits. Therefore, might be reflected on the yield and its components such as fruit length, fruit diameter, average fruit weight and number of fruits per plant. Al-Rubaye and Atia, (2016) exhibited that foliar spraying with salicylic acid caused the highest of number of fruits, total yield per plant and total yield per hectare compared to the untreated plants. In addition, Sahin et al., (2015) exhibited that, calcium and boron treatments increased the yield and its components. The present results are in agreement with those obtained by Mady, (2009) and Hendawy and Ezz El-Din (2010) on vitamin E, Shafeek et al. (2013) on calcium nitrate, Nasrollahzadeh et al. (2015) on boric acid, Al-Rubaye and Atia, (2016) on zinc, Salem (2018) on glycine betaine .

Table 4: Effect of foliar application with some treatments on yield and fruit quality traits of summer squash plants during two seasons of 2017 and 2018.

\begin{tabular}{|c|c|c|c|c|c|c|c|}
\hline \multirow{2}{*}{ Treatments } & \multirow[t]{2}{*}{ Traits } & \multicolumn{2}{|c|}{ Fruit length (cm) } & \multicolumn{2}{|c|}{$\begin{array}{c}\text { Fruit diameter } \\
(\mathrm{cm})\end{array}$} & \multicolumn{2}{|c|}{$\begin{array}{c}\text { Average fruit weight } \\
\text { (g) }\end{array}$} \\
\hline & & 2017 & 2018 & 2017 & 2018 & 2017 & 2018 \\
\hline Control & & 10.97 & 10.39 & 3.55 & 3.67 & 90.87 & 94.20 \\
\hline Vitamin $C$ at 100 ppm & & 13.98 & 15.47 & 2.93 & 3.33 & 121.88 & 127.72 \\
\hline Vitamin $E$ at $100 \mathrm{ppm}$ & & 13.60 & 14.12 & 2.83 & 2.70 & 116.39 & 117.37 \\
\hline Potassium silicate at100ppm & & 14.94 & 15.86 & 2.44 & 2.80 & 125.64 & 134.05 \\
\hline Salicylic acid at 50ppm & & 13.98 & 14.73 & 2.33 & 2.70 & 112.14 & 113.04 \\
\hline Glycine betaine at $75 \mathrm{ppm}$ & & 12.98 & 13.80 & 2.67 & 2.60 & 107.15 & 110.34 \\
\hline Urea at $1 \%$ & & 12.57 & 13.75 & 2.54 & 2.90 & 100.59 & 100.23 \\
\hline Ca nitrate at $0.5 \%$ & & 13.65 & 14.00 & 2.70 & 2.96 & 123.13 & 132.04 \\
\hline Boric acid at $60 \mathrm{ppm}$ & & 12.29 & 13.01 & 3.05 & 3.27 & 102.42 & 103.00 \\
\hline Zn chelated at $50 \mathrm{ppm}$ & & 12.97 & 12.56 & 2.91 & 3.17 & 107.38 & 110.96 \\
\hline LSD $1 \%$ & & 0.533 & 1.950 & 0.105 & 0.707 & 1.503 & 5.140 \\
\hline LSD $5 \%$ & & 0.389 & 1.430 & 0.077 & 0.516 & 1.097 & 3.752 \\
\hline
\end{tabular}

Table 4: continued

\begin{tabular}{|c|c|c|c|c|c|c|c|}
\hline \multirow{2}{*}{ Treatments } & \multirow[t]{2}{*}{ Traits } & \multicolumn{2}{|c|}{$\begin{array}{c}\text { Number of fruits / } \\
\text { plant }\end{array}$} & \multicolumn{2}{|c|}{$\begin{array}{c}\text { Total yield / plant } \\
\text { (kg) }\end{array}$} & \multicolumn{2}{|c|}{$\begin{array}{c}\text { Total yield / } \\
* \text { Feddan (ton) }\end{array}$} \\
\hline & & 2017 & 2018 & 2017 & 2018 & 2017 & 2018 \\
\hline Control & & 8.33 & 8.33 & 0.76 & 0.79 & 6.06 & 6.27 \\
\hline Vitamin $C$ at 100 ppm & & 9.67 & 11.33 & 1.18 & 1.45 & 9.42 & 11.58 \\
\hline Vitamin $E$ at $100 \mathrm{ppm}$ & & 9.33 & 10.67 & 1.09 & 1.25 & 8.69 & 10.02 \\
\hline Potassium silicate at100ppm & & 10.33 & 12.33 & 1.30 & 1.65 & 10.39 & 12.23 \\
\hline Salicylic acid at 50ppm & & 9.33 & 11.00 & 1.05 & 1.25 & 8.37 & 9.96 \\
\hline Glycine betaine at $75 \mathrm{ppm}$ & & 8.33 & 9.67 & 0.90 & 1.07 & 7.15 & 8.56 \\
\hline Urea at $1 \%$ & & 9.67 & 10.00 & 0.97 & 1.00 & 7.78 & 8.02 \\
\hline Ca nitrate at $0.5 \%$ & & 8.33 & 9.33 & 1.03 & 1.23 & 8.21 & 9.87 \\
\hline Boric acid at $60 \mathrm{ppm}$ & & 8.33 & 9.67 & 0.86 & 1.00 & 6.83 & 7.97 \\
\hline Zn chelated at $50 \mathrm{ppm}$ & & 9.33 & 10.33 & 1.00 & 1.15 & 8.02 & 9.19 \\
\hline LSD $1 \%$ & & 1.270 & 1.842 & 0.140 & 0.239 & 1.120 & 1.719 \\
\hline LSD $5 \%$ & & 0.927 & 1.345 & 0.102 & 0.175 & 0.819 & 1.201 \\
\hline
\end{tabular}




\section{Chemical constituents:}

The obtained results in Table 5 showed the chemical constituents (Total chlorophyll, N, P, K, $\mathrm{Si}$, TSS and Vitamin C) of summer squash as influenced by the foliar application of different treatments during the seasons of 2017 and 2018. Concerning chlorophyll index, the results revealed that, the highest readings values were found when plants treated with $100 \mathrm{ppm}$ potassium silicate followed by treating plants with urea at $1 \%$ compared to untreated plants during the first and second seasons. This finding could be taken place due to the major role of potassium silicate on photosynthetic activity, ultra-structure of leaf organelles, photosynthetic rate and photosynthetic pigments in leaves (Mady 2009).

Table 5: Effect of foliar application with some treatments on chemical constituent's traits of summer squash during two seasons of 2017 and 2018.

\begin{tabular}{lllllllll}
\hline & \multicolumn{2}{c}{$\begin{array}{c}\text { Total } \\
\text { Traits } \\
\text { Treatments }\end{array}$} & \multicolumn{2}{c}{$\begin{array}{c}\text { Nitrogen } \\
\text { (SPAD) }\end{array}$} & \multicolumn{2}{c}{$\begin{array}{c}\text { Phosphorus } \\
\mathbf{( \% )}\end{array}$} & \multicolumn{2}{c}{$\begin{array}{c}\text { Potassium } \\
\text { (\%) }\end{array}$} \\
\cline { 2 - 9 } & $\mathbf{2 0 1 7}$ & $\mathbf{2 0 1 8}$ & $\mathbf{2 0 1 7}$ & $\mathbf{2 0 1 8}$ & $\mathbf{2 0 1 7}$ & $\mathbf{2 0 1 8}$ & $\mathbf{2 0 1 7}$ & $\mathbf{2 0 1 7}$ \\
\hline Control & 19.74 & 20.11 & 0.85 & 0.87 & 0.296 & 0.300 & 2.09 & 2.06 \\
Vitamin C at 100 ppm & 30.83 & 32.29 & 1.28 & 1.29 & 0.460 & 0.462 & 2.56 & 2.58 \\
Vitamin E at 100 ppm & 29.41 & 31.22 & 1.38 & 1.41 & 0.468 & 0.472 & 2.40 & 2.43 \\
Potassium silicate at 100ppm & 32.46 & 33.39 & 1.29 & 1.31 & 0.459 & 0.462 & 3.14 & 3.13 \\
Salicylic acid at 50ppm & 31.70 & 33.81 & 1.46 & 1.49 & 0.499 & 0.502 & 2.56 & 2.63 \\
Glycine betaine at 75ppm & 35.96 & 36.99 & 1.61 & 1.59 & 0.530 & 0.533 & 2.96 & 3.00 \\
Urea at 1 \% & 33.80 & 34.26 & 1.58 & 1.59 & 0.510 & 0.512 & 2.40 & 2.42 \\
Ca nitrate at 0.5 \% & 26.48 & 28.48 & 1.48 & 1.50 & 0.475 & 0.474 & 2.33 & 2.37 \\
Boric acid at 60 ppm & 29.52 & 30.81 & 1.54 & 1.52 & 0.489 & 0.492 & 2.49 & 2.51 \\
Zn chelated at 50 ppm & 28.49 & 30.64 & 1.52 & 1.53 & 0.479 & 0.483 & 2.46 & 2.50 \\
\hline LSD 1 \% & $\mathbf{1 . 6 5 4}$ & $\mathbf{2 . 5 6 6}$ & $\mathbf{0 . 0 4 1}$ & $\mathbf{0 . 0 6 0}$ & $\mathbf{0 . 0 0 6}$ & $\mathbf{0 . 0 0 7}$ & $\mathbf{0 . 0 7 9}$ & $\mathbf{0 . 0 5 2}$ \\
LSD 5 \% & $\mathbf{1 . 2 0 7}$ & $\mathbf{1 . 8 7 2}$ & $\mathbf{0 . 0 3 0}$ & $\mathbf{0 . 0 4 4}$ & $\mathbf{0 . 0 0 5}$ & $\mathbf{0 . 0 0 2}$ & $\mathbf{0 . 0 5 7}$ & $\mathbf{0 . 0 3 8}$ \\
\hline
\end{tabular}

Table 5: Continued

\begin{tabular}{lcccccc}
\hline \multirow{2}{*}{ Treatments } & Traits & \multicolumn{2}{c}{$\begin{array}{c}\text { Silicon } \\
(\mathbf{\%})\end{array}$} & \multicolumn{2}{c}{$\begin{array}{c}\text { Total soluble solid } \\
(\mathbf{\%})\end{array}$} & \multicolumn{2}{c}{$\begin{array}{c}\text { Vitamin C } \\
(\mathbf{m g} / \mathbf{1 0 0 g})\end{array}$} \\
\cline { 2 - 7 } & $\mathbf{2 0 1 7}$ & $\mathbf{2 0 1 8}$ & $\mathbf{2 0 1 7}$ & $\mathbf{2 0 1 8}$ & $\mathbf{2 0 1 7}$ & $\mathbf{2 0 1 8}$ \\
\hline Control & 0.28 & 0.29 & 2.84 & 2.60 & 9.82 & 9.86 \\
Vitamin C at 100 ppm & 0.53 & 0.54 & 4.65 & 4.91 & 13.88 & 13.91 \\
Vitamin E at 100 ppm & 0.56 & 0.58 & 4.31 & 4.28 & 13.55 & 13.59 \\
Potassium silicate at 100 ppm & 0.66 & 0.67 & 5.09 & 5.90 & 11.58 & 11.69 \\
Salicylic acid at 50 ppm & 0.52 & 0.54 & 4.81 & 4.93 & 11.37 & 11.51 \\
Glycine betaine at 75 ppm & 0.47 & 0.48 & 4.11 & 4.29 & 12.24 & 11.35 \\
Urea at 1 \% & 0.43 & 0.42 & 4.00 & 4.48 & 12.56 & 12.62 \\
Ca nitrate at 0.5 \% & 0.48 & 0.50 & 4.29 & 4.33 & 12.84 & 12.91 \\
Boric acid at 60 ppm & 0.59 & 0.58 & 3.58 & 3.87 & 12.59 & 12.70 \\
Zn chelated at 50 ppm & 0.58 & 0.60 & 3.95 & 4.14 & 13.59 & 13.64 \\
\hline LSD 1 \% & $\mathbf{0 . 0 2 4}$ & $\mathbf{0 . 0 5 1}$ & $\mathbf{0 . 1 2 9}$ & $\mathbf{0 . 4 4 0}$ & $\mathbf{0 . 3 4 6}$ & $\mathbf{0 . 2 1 6}$ \\
LSD 5\% & $\mathbf{0 . 0 1 7}$ & $\mathbf{0 . 0 3 7}$ & $\mathbf{0 . 0 9 4}$ & $\mathbf{0 . 3 2 1}$ & $\mathbf{0 . 2 5 3}$ & $\mathbf{0 . 1 5 8}$ \\
\hline
\end{tabular}

Further, this event may be occurred owing to ability salicylic acid and / or potassium silicate to regulate the leaf photosynthetic functions as in case of cucumber readings (Wei et al., 2009). Photosynthetic pigments in leaves of wheat plants were significantly increased by application of vitamin C (Amin et al., 2007). El-Tohamy et al. (2006) found that foliar application of calcium chloride maintained higher total chlorophyll content. The stimulative influence of vitamin $\mathrm{E}$ may be due to their antioxidantal scavenging effect to be forfended chloroplasts and prevented chlorophyll degradation by the toxic reactive oxygen radicals (Mady 2009). The obtained results reported that the lowest content of N, P, K and Si in leaves were obtained from untreated plants during both seasons. While, the highest percentages of $\mathrm{N}$ and $\mathrm{P}$ were obtained when plants treated with $75 \mathrm{ppm}$ glycine betaine during the two seasons, respectively followed by urea at $1 \%$ in both seasons, consequently. Regarding $\mathrm{K}$ content in leaves, the results showed that the highest percentages were obtained from 
plants treated with $100 \mathrm{ppm}$ potassium silicate followed by $75 \mathrm{ppm}$ glycine betaine in both seasons. Concerning to leaves content of $\mathrm{Si}$, plants treated with $100 \mathrm{ppm}$ potassium silicate exhibited the highest concentration in both seasons followed by $60 \mathrm{ppm}$ boric acid. It is also due to the foliar urea fertilization during crop growth can improve the mineral status of plants and increase the vigor of plant. These results agree with those reported by Mady, (2009) on vitamin E; Jafari et al. (2015) reported that under osmotic stress silicon treatment significantly increased non-enzymatic antioxidants, total phenolic compounds, anthocyanins, flavonoids, $\mathrm{Si}, \mathrm{K}^{+}$and $\mathrm{Ca}^{+2}$ content in cucumber plants. Omar (2017) illustrated that foliar application of silicon caused significant increase in cucumber N, P, K and Si leaves percentage compared to untreated plants.

The results in the same table revealed that the lowest TSS values of fruits were recorded during both seasons from untreated plants compared to other treatments. The highest values were gained from the plants sprayed with $100 \mathrm{ppm}$ potassium silicate (5.09 and 5.90) followed by $50 \mathrm{ppm}$ salicylic acid (4.81 and 4.93), respectively in both seasons of the study. In addition, the results cleared that the highest vitamin $C$ values are associated with the plant which sprayed by vitamin $C$ at $100 \mathrm{ppm}$ followed by $100 \mathrm{ppm}$ vitamin E compared to untreated plants (control) during both seasons. In general, it could be summarized that, the highest nutritional magnitudes were associated with that plants which sprayed with potassium silicate at $100 \mathrm{ppm}$ but, the lowest values were resulted with untreated plants (control). Foliar application of salicylic acid at $200 \mathrm{ppm}$ or potassium silicate at 100 ppm caused; significant increase in total soluble solids of cucumber fruits compared to control plants (Al-Rubaye and Atia 2016; Omar 2017). Furthermore, on squash plants Abd -Elaziz et al. (2019) found that total soluble solids of fruits had significantly affected by the application of potassium silicate and salicylic acid. Similar results were obtained by Noufal et al. (2018) on vitamin C. These results are in harmony with those reported by Al-Rubaye and Atia (2016) on zinc, Abd El-Mageed et al. (2016) and Abd- El aziz et al. (2019) on salicylic acid.

In general, it could be said that spraying potassium silicate at $100 \mathrm{ppm}$ and glycine betaine at $75 \mathrm{ppm}$ can be recommended for improving growth, yield and quality of summer squash under heat stress conditions of Dakahlia Governorate and other similar regions.

\section{References}

A.O.A.C., 1990. Official methods of analysis, $12^{\text {th }}$ Ed Association of Official Analytical Chemists. Washington, D.C.

Abd El-Aal F., S., A. M. Shaheen, A. A. Ahmed and M. R. Asmaa, 2010. Effect of foliar application of urea and amino acids mixtures as antioxidants on growth, yield and characteristics of squash. R.J. Agric. and Bio. Sci., 6 (5): $582-588$.

Abd El-All, H.M., S.M. Ali and S.M. Shahin, 2013. Improvement growth, yield and quality of squash (Cucurbita pepo, L.) plant under salinity conditions by magnetized water, amino acids and selenium. J. Applied Sci. Res., 9: 937- 944.

Abd El-Gawad, H.G. and H.S. Osman, 2014. Effect of exogenous application of boric acid and seaweed extract on growth, biochemical content and yield of eggplant. Journal of Horticultural Science and Ornamental Plants, 6: 133-143.

Abd El-Mageed, T.A., W. M. Semida, G.F. Mohamed and M.M. Rady, 2016. Combined effect of foliar-applied salicylic acid and deficit irrigation on physiological anatomical responses and yield of squash plants under saline soil. South African J. Botany, 106: 8-16.

Abd-Elaziz. S.A., A.A. Alkharpotly, M.M. Yousry and A.I.A. Abido, 2019. Effect of foliar application with salicylic acid and potassium silicate on squash plants (Cucurbita pepo, L.) yield and quality. Fayoum J. Agric. Res. and Development, 33 (1):1 - 25.

Al-Rubaye, B.C.H. and E.A. Atia, 2016. The influence of foliar sprays on the growth and yield of summer squash. International J. Scientific and Engineering Research, 7 (6): 664 -669.

Amin, A.A., E.S.M. Rashad and H.M.H. El- Abagy, 2007. Physiological effect of indole- butyric acid and salicylic acid on growth, yield and chemical constituents of onion plants. J. Appl. Sci. Res., 3:1554 -1563.

APHA, 1992. Standard method for the examination of water and wastes water. $18^{\text {th }}$ ed. American Public Health Association, Washington. D.C. 
Ashraf, M., 2004. Some important physiological selection criteria for salt tolerance in plants. Flora, 199: 361- 376.

Buczkowska, H., Z. Michałojć and R. Nurzyńska-wierdak, 2016. Yield and fruit quality of sweet pepper depending on foliar application of calcium. Turkish Journal of Agriculture and Forestry, 40: 222-228.

Dreesen P. E., H.J. De Boeck; I. A. Janssens and I. Nijs, 2012. Summer heat and drought extremes trigger unexpected changes in productivity of a temperate annual / biannual plant community. Environ. Exp. Bot., 79: 21-30.

El-Tohamy W.A., H.M. El-Abgay and N.H.M. El-Greadly, 2008. Studies on the effect of putrescine, yeast and vitamin $\mathrm{C}$ on growth, yield and physiological response of eggplant (Solanum melongena L.) under sandy soil conditions. Aust. J. Basic. Appl. Sci., 2(2): 296-300.

El-Tohamy, W.A., A.A. Ghoname and S.D. Abou-Hussein, 2006. Improvement of pepper growth and productivity in sandy soil by different fertilization treatments under protected cultivation. Journal of Applied Sciences Research, 2, 8 -12.

Elwan, M.W.M. and R.S.A. EL-Shatoury, 2014. Alleviation of $\mathrm{NaCl}$ stress in summer squash'Eskandrani' by foliar application of salicylic acid. J. Hort. Res., 22(2): 131-137.

Esringü, A., M. Turan, A. Gunes, A. Eşitken and P. Sambo, 2011. Boron application improves on yield and chemical composition of strawberry'. Acta Agriculturae Scandinavica, Section B Plant Soil Science, 61: 245-252.

Hendawy S.F. and A.A. Ezz El-Din, 2010. Growth and yield of Foeniculum vulgar, var. Azoricum as influensed by some vitamins and amino acids. Ozean J. Appl. Sci., 3(1): 113-123.

Iqbal, N.; S. Umar; N. A. Khan and M. I. R. Khan, 2014. A new perspective of phytohormones in salinity tolerance: regulation of praline metabolism. Environ. Exp. Bot., 100: 34 - 42.

Jafari, S.R., S.M.J. Arvin and K.M. Kalantari, 2015. Response of cucumber (Cucumis sativus, L.) seedlings to exogenous silicon and salicylic acid under osmotic stress. Acta Biologica Szegediensis, 59(1): 25 - 33 .

Jaleel C.A., P. Manivannan, M. Gomathinayagam; R. Sridharan and R. Panneerselvam, 2006. Response of antitoxidant potentials in Dioscora rotundata, Poir. Following paclobutrazol drenching. Com. Ren. Biol., 330: 798 - 805.

Lalelou, F. S. and M. Fateh, 2014. Effects of different concentration of zinc on chlorophyll, starch, soluble sugars and proline content of Cucurbita pepo. International J. Biosciencess, 4(10): 6 12.

Liang, Y., M. Nikolic; R. Bélanger; H. Gong and A. Song, 2015. Silicon in Agriculture. Springer Dordrecht Heidelberg, New York, 250.

Mady, M.A., 2009. Effect of foliar Application with salicylic acid and vitamin E on growth and productivity of tomato (Lycopersicon escylentym, Mill.) plant. J. Agric. Sci. Mansoura Univ., 34 (6): 6735 - 6746.

Mageed K.A.A., 2010. Effect of calcium nitrate, potassium nitrate and anfaton on growth and storability of plastic houses cucumber (Cucumis sativus, L.) American Journal of Plant Physiology, 5 (5): $278-290$.

Marquard, R. D. and J. L. Tipton, 1987. Relationship between extractable chlorophyll and an in situ method to estimate leaf greenness. Hort Science, 22 (6): p.1327.

Matichenkov, V. and E. Bocharnikova, 2008. New generation of silicon fertilizers. PP. 71. In Malcolm Keeping (ed.) silicon in Agriculture Conference South Africa, 2008. 4th International conference Abstracts .University of Kwazulu -Natal, Wild cost sun, port Edward, Kwazulu-Natal, South Africa.

Mazher, A.A.M., S.M. Zaghloul, S.A. Mahmoud and H.S. Siam, 2011. Stimulatory effect of kinetin, ascorbic acid and glutamic acid on growth and chemical constituents of Codiaeum variegatum, L. plants. American-Eurasian Journal of Agriculture and Environmental Science, 10 (3): 318-323.

Mazid, M., T.A. Khan, Z.H. Khan; S. Quddusi and F. Mohammad, 2011. Occurrence, biosynthesis and potentialities of ascorbic acid in plants. International Journal of Plant, Animal and Environmental Sciences, 1(2): 167-184.

Mazumdar, B. C. and K. Majumder, 2003. Methods on Physicchemical Analysis of Fruits. Univ. Cokkege of Agric. Calcutta Univ., 108 - 109. 
Mumivand, H., M. Babalar, J. Hadian and S. M. Tabatabaei, 2010. Influence of nitrogen and calcium carbonate application rates on the minerals content of summer savory (Satureja hortensis, L.) leaves, Hort. Environ. Biotechnol., 51(3): 173 - 177.

Murphy, J. and J.P. Riely, 1962. A modified single solution method for determination of phosphate in natural waters. Anal. Chim. Acta, 29: 31 - 36.

Nasrollahzadehasl, N., M. Delshad and A.K. Kashi, 2015. The effects of foliar application of urea, calcium nitrate and boric acid on growth and yield of greenhouse Cucumber. Biological Forum - An International Journal, 7(1): 712-720.

Noman, R., S.H. Raza, M. Qasim and N. Iqbal, 2011. Pre-sowing application of ascorbic acid and salicylic acid to seed of pumpkin and seedling response to salt. Pak. J. Bot., 43(6): 2677-2682.

Noufal, E. H. A., M.A.M. Ali and M.M.M. Abd El-Aal, 2018. Effect of rhizobium inoculation and foliar spray with salicylic and ascorbic acids on growth, yield and seed quality of pea plant (Pisum sativum, L.) grown on a salt affected soil, New Valley-Egypt. $4^{\text {th }}$ International Conference on Biotechnology Applications in Agriculture (ICBAA), Benha University, Moshtohor and Hurghada, 4-7 April. Egypt 573 - 590.

Okalebo, J. R., K.W. Cuthua and P. J. Woomer, 2002. Laboratory methods of soil and plant analysisA working manual. TSBF- CIAT and SACRED Africa, Nairobi, Kenya. Pp. 128.

Omar, A.A.A., 2017. Improving the fruit yield and quality of the grafted cucumber plants grown under high polyethylene tunnels. M.Sc. thesis, Fac. Agric. Mansoura Univ. Egypt, 69 p.

Pregl, E., 1945. Quantitative Organic Micro Analysis. ${ }^{\text {th }}$ Ed. J. Chundril, London.

Rizwan, M.A., S. Ibrahim, M. Farid, M. Adrees, M. Bharwana and S.A. Etal, 2015. Mechanisms of silicon-mediated alleviation of drought and salt stress in plants: a review. Environ. Sci. Pollut., Res., 22: 15416 - 15431.

Rollins J. A., E. Habte, S. E. Templer, T. Colby, J. Schmidt and M. Von Korff, 2013. Leaf proteome alterations in the context of physiological and morphological responses to drought and heat stress in barley (Hordeum vulgare, L.) J. Exp. Botany, 64(11): 3201 - 3212.

Şahin, S., N. Gebologlu and M. R. Karaman, 2015. Interactive effect of calcium and boron on growth, quality and mineral content of tomato (Solanum lycopersicon, L.) Fresenius Environmental Bulletin, 24, 1624 - 1628.

Salama, Z. A.; El. A. A. Abou El-Nour; M. M. El Fouly, and A. G. Alaa, 2014. Ascorbic acid foliar spray counteracting effect of salinity on growth, nutrients concentrations, photosynthesis, antioxidant activities and lipid peroxidation of bean (Phaseulus vulgaris, L.) cultivars. Am. J. Agric. Biol. Sci., 9 (3): 384 - 393.

Salem S. A. A., 2018. Effect of water stress and some anti transpirants on growth, yield and quality of okra plants (Abelmoschus esculentus. M. Sc. thesis, Fac. Agric. Mansoura Univ. Egypt., 85 p.

Sekhon H.S., G. Singh, P. Sharma and T. S. Bains, 2010. Water use efficiency under stress environments. in: Climate change and management of cool season grain legume crops (Eds) S.S. Yadav; D.L. Mc Neil; R. Redden and S.A. Patil. Springer Press, Dordrecht-HeidelbergLondon-New York.

Shafeek M. R., Y. I. Helmy, W. A. El-Tohamy and H. M. El-Abagy, 2013. Change in growth, yield and fruit quality of cucumber (Cucumis sativus, L. in response to foliar application of calcium and potassium nitrate under plastic house conditions. Res. J. Agri. and Bio. Sci., 9(3): 114 118.

Snedecor, G.W. and W.G. Cochran, 1982. Statistical Methods $7^{\text {th }}$ Ed. Iowa State Univ. Press, Ame., USA., 507 p.

Szabados, L. and A. Savouré, 2010. Proline: A multifunctional amino acid. Trends Plant Sci., 15: 89 97.

Tamer, C.E., B. Incedayi, A. S. Parseker; S. Yonak and O. U. Copur, 2010. Evaluation of several quality criteria of low calorie pumpkin dessert. Not. Bot. Horti. Agrobot. Cluj-Napoca, 38:76 -80 .

Wei, L., A. Xi-Zhen, L. Wen-Juan, W. Hong-Tao, L. Sheng-Xue and Z. Nan, 2009. Effects of salicylic acid on the leaf photosynthesis and antioxidant enzyme activities of cucumber seedlings under low temperature and light intensity. Yingyong Shengtai Xuebao, 20(2): 441445 . 
Xu-fuli, L., Y. Liang, C. Zhang and C. Du- Sheni, 2004. Effect of fertilizer application on nitrate contents in the soil and in sunlight green house. Grown Cucumber, Journal article.

Youssef, E.A.E., M. M. A. El-Baset, A.F. El-Shafie and M.M. Hussein, 2017. Study the applications of water deficiency levels and ascorbic acid foliar on growth parameters and yield of summer squash plant. Agricultural Engineering International: CIGR Journal, Special issue: 147 - 158. 